\title{
Latvia's Pērkonkrusts: Anti-German National Socialism in a Fascistogenic Milieu
}

\author{
Matthew Kott \\ Uppsala University, Sweden \\ matthew.kott@ucrs.uu.se
}

\begin{abstract}
Aside from equating it with Hitlerism, there have been few scholarly attempts to define national socialism and specify its relation to the broader category of fascism. This article posits that national socialisms are a sub-genus of fascism, where the distinguishing feature is an ultaranationalism based on a palingenetic völkisch racism, of which antiSemitism is an essential element. Thus, national socialism is not just mimetic Hitlerism, as Hitler is not even necessary. National socialist movements may even conceivably be opposed to the goals and actions of Hitlerism. To test this definition, the case of Latvia's Pèrkonkrusts [Thunder Cross] movement is analysed. Based on an analysis of its ideology, Pērkonkrusts is a national socialist movement with a völkisch racialist worldview, while also being essentially anti-German. The case study even addresses the apparent paradox that Pêrkonkrusts both collaborated in the Holocaust, and engaged in resistance against the German occupation regime.
\end{abstract}

\section{Keywords}

national socialism - völkisch ideology - anti-Semitism - Latvia - Pērkonkrusts Gustavs Celmiņš - collaboration - resistance

\section{National Socialisms as a Fascist Sub-Genus}

Of the vast and growing corpus of scholarly and popular literature on national socialism - usually pertaining to Nazi Germany - very rarely is this fundamental concept defined. The reasons for this could be twofold. Firstly, it might be assumed as self-evident that 'national socialism' is simply synonymous with 
the mid-twentieth century German version of National Socialism (also known as 'Nazism' or 'Hitlerism') associated with Adolf Hitler and his NSDAP. In the case of national socialist organisations outside of Germany, these are either de facto subsidiaries of the German mother party, or derivative, mimetic movements. In this view, any party with a swastika as its emblem and a violently anti-Semitic ultranationalist platform simply could be assumed an unoriginal copycat, seeking to exploit the success of the NSDAP in Germany.

Should one observe European history in the years between 1920 and 1945 from the periphery, or even simply from a non-Germanocentric perspective, this assumption of subordination or mimesis quickly proves itself unsatisfactory for explaining aspects of, for example, local collaboration in those countries occupied by Nazi Germany during the Second World War. ${ }^{1}$ How could there have existed what my colleague Terje Emberland has termed an 'oppositional national socialism' in wartime Norway, which both collaborated closely with the ss, and also opposed many of the policies of the German NSDAP and the collaborationist Nasjonal Samling [NS; National Unity] regime of Vidkun Quisling?2 Our research on Norway thus suggests that not only amongst Norwegians were there different, competing understandings of national socialism, but that also within German Nazism there were even significant differences between Himmler's ss and the mainstream NSDAP ideology. ${ }^{3}$ Thus, it would be preferable to speak not of a single National Socialism, but of national socialisms in the plural.

Another significant obstacle to the formulation of a general definition of national socialism stems from the resistance in certain circles to accepting it as a phenomenon within the broader category of fascism. Much of this criticism derives from the argument that, by positing generic fascism as an umbrella term, many of the unique, particular, and defining features of German National Socialism are either lost or obscured. ${ }^{4} \mathrm{John}$ Lukacs, in a rather muddled way that still does not actually define what constitutes national socialism, has even argued that national socialism, and not fascism, should be the universal category for historical analysis. ${ }^{5}$ Ian Kershaw, however, makes convincing arguments for

1 Terje Emberland and Matthew Kott, Himmlers Norge: Nordmenn i det storgermanske prosjekt (Oslo: Aschehoug 2012), 496.

2 See the contribution by Terje Emberland in this volume.

3 Emberland and Kott, Himmlers Norge, passim.

4 Ian Kershaw, The Nazi Dictatorship: Problems and Perspectives of Interpretation, 3rd edition (London: Edward Arnold, 1993), 34-35.

5 John Lukacs, 'The Universality of National Socialism (The Mistaken Category of "Fascism”),' Totalitarian Movements and Political Religions 3 (2002): 107-121. Lukacs here identifies fascism as being synonymous with Mussolinian Italian Fascism. 
why German National Socialism should be properly included within the family of fascisms, all of which had their own unique and particular characteristics. ${ }^{6}$

To assume that there is a generic fascism of which German National Socialism is a specific expression, and that there are not just one, but several national socialisms, would sooner or later necessitate augmenting the taxonomy by defining a national socialist sub-genus. Building on the definition of generic fascism proposed by Roger Griffin, the following general definition of national socialism is proposed: Given that '[f]ascism is a genus of political ideology whose mythic core in its various permutations is a palingenetic form of populist ultra-nationalism, ${ }^{7}$ then national socialism is a type of fascism where the populist ultranationalism is based on palingenetic völkisch racism, of which anti-Semitism is an essential element. Thus, I posit that the distinguishing feature of national socialisms within the broader family of fascisms is the centrality of a völkisch, racialist worldview. ${ }^{8}$

As Griffin has pointed out, all fascisms are to some degree 'racist', insofar as ultranationalism celebrates the greatness of one's own nation and culture, thereby fostering a sense of superiority over other peoples. Fascist ideology is thus intrinsically hostile to liberal multiculturalism, free migration, and other individual-driven mixings of peoples, religions, and cultures. At the same time, this does not necessarily mean that all fascisms must embrace racist positions e.g. social Darwinism, eugenics, or even anti-Semitism - as central to their understanding of their nation's relation to society and the world. ${ }^{9}$

Within national socialism, however, the nation is always organically linked to the race: just as the organically conceived nation (Volk) provides the genotype for the individual's phenotype, so, too, does each nation reflect a phenotype of the genotype provided by the common racial identity. ${ }^{10}$ Maintaining the racial Erbbild [genotype] and improving the Erscheinungsbild [phenotype]

6 Kershaw, The Nazi Dictatorship, 39.

7 Roger Griffin, The Nature of Fascism (London: Routledge, 1993), 2.

8 Depending on how 'völkisch' is defined, there can be some debate as to whether the NSDAP was a völkisch political movement, or not, e.g.: Samuel Koehne, 'Were the National Socialists a Völksich Party? Paganism, Christianity, and the Nazi Christmas,' Central European History 47 (2014): 760-790, accessed October 20, 2015, doi: 10.1017/ Sooo8938914001897. Despite admitting that it was not a particularly clear-cut concept, Hitler nevertheless said that the völkisch worldview was the basis for the ideology of German National Socialism: Adolf Hitler, Mein Kampf (Berlin: Franz Eher, 1934), 415-420.

10 Pidder Lüng [Martin Löpelmann], National-Sozialismus (Berlin: Pan-Verlag, 1931), 20-21; Mintauts Plāḳis, 'Nācija un rase,' Lìdums, 16 March 1944. 
of both individuals and the entire Volk was a key concern of German National Socialism, ${ }^{11}$ particularly for Heinrich Himmler and the ss. ${ }^{12}$

Even though this impetus to improve the racial stock of the nation can lead national socialists to support the introduction of eugenic policies in the name of 'racial hygiene', this should not be taken as evidence that national socialists subscribe to a rationalist, positivist view of race as a supposedly biological phenomenon. Upon closer inspection, racial ideology in national socialism has only relatively superficial traits in common with, for example, the 'scientific' racial biology and eugenics practised in interwar Scandinavia, which was connected to the social engineering of a new, modern society. ${ }^{13}$

Racialist thinking in national socialism is neither rationalist, nor aiming towards modernisation. Instead, it is völkisch racialism, derived from the ideological worldview of the völkisch movement that began in the late nineteenth century. ${ }^{14}$ Völkisch racism fostered a sacralised view of an assumed prehistoric Aryan race, from whence the most advanced nations and civilizations of the world arose. In the case of the inter-war German and Scandinavian national socialists, the highest rungs of the racial hierarchy were seen as being occupied by Germanic or Nordic peoples; however among national socialist movements since 1945 the emphasis is more on global 'white supremacy' of light-skinned groups of Europeans generally. ${ }^{15}$ Nevertheless, a clear bias towards an idealized 'Nordic' identity infuses national socialism, even in societies that are not usually considered 'Germanic'.

From this view of the relationship between race and nation, national socialism also has aspects of what Griffin has called 'fascist internationalism,, ${ }^{16}$ albeit in each case this is expressed with varying amounts of emphasis. Since neighbouring nations are seen often to share common cultural and racial ties, national socialists can view such clusters of nations as natural allies in the

1 Lüng, National-Sozialismus, 20-26.

12 Emberland and Kott, Himmlers Norge, $185^{-186 .}$

13 See, for example, Gunnar Broberg and Mattias Tydén, Ö̈nskade i folkhemmet: Rashygien och sterilisering i Sverige, 2nd edition (Stockholm: Dialogos, 2005).

14 For a summary of the völkisch worldview, see: 'Völkische Weltanschauug', in Realliexikon der Germanischen Altertumskunde, Volume 32, ed. Heinrich Beck, Dieter Geuenich and Heiko Steuer (Berlin: De Gruyter 2006), 522-538. A more detailed discussion of the various tensions between völkisch ideology, Aryanism, and Nordicism can be found in: Christopher M. Hutton, Races and the Third Reich: Linguistics, Racial Anthropology, and the Dialectic of the Volk (Cambridge: Polity, 2005).

15 For example: 'A Racist Catechism,' in Griffin, Fascism, 327.

16 Griffin, Fascism, 8. 
eternal struggle amongst the races of the world. These can form communities of shared blood (Blutsgemeinschaft) or of shared fate (Schicksalsgemeinschaft), where the national socialists' own nation is usually seen as primus inter pares in the project to build a new continental or global order. Within German National Socialism this internationalist tendency was most strongly expressed in the explicit pan-Germanism of Himmler and the ss. ${ }^{17}$

Coupled with the mythology of race is a view that races and nations are formed in symbiosis with their physical surroundings, with the land being the source of many of the physical and spiritual characteristics of the Volk. A strong connection to both the natural and cultural landscape is thus important for maintaining the vigour of the nation. Life in cities alienates the individual from the moral compass that being one with the soil provides, leading to racial and cultural dilution and degeneration. In its völkisch racism, national socialism thus is an ideology of Blut und Boden [blood and soil], favouring the pure, healthy peasant ways to the modern, urban, materialistic lifestyle that was both morally and physically hazardous. As Hitler wrote in Mein Kampf: 'Just the possibility of maintaining a healthy peasantry as the foundation for the entire nation can never be overestimated. ${ }^{18}$ The racial and cultural rebirth of the nation will be accomplished in national socialism by the rejection of the modern, urban, and false in favour of the natural, rural, and authentic.

The antithesis of all that national socialism strives for can be found in the construct of the Jew. In national socialist anti-Semitism, the Jew represents not only modernity, urbanism, immorality, capitalism, materialism, Marxism, and a host of other social and spiritual ills, the Jew is also a racial other. More than just foreigners or an ethnic minority, Jews are an alien race whose every activity aims to subordinate and degenerate other peoples. Despite the various local contexts of national socialisms in different societies, the Jew as global conspirator is always a primary enemy for national socialists. The universality and centrality of anti-Semitism to national socialism places it in a separate category from other kinds of fascist xenophobia and racism, even other fascists' anti-Semitism. ${ }^{19}$ Within national socialism, typical fascist characteristics like anti-Marxism, anti-liberalism, anti-capitalism, or anti-conservatism, are secondary to or by-products of this völksich anti-Semitism. ${ }^{20}$

\footnotetext{
17 This is one of the main premises of Emberland and Kott, Himmlers Norge.

18 Hitler, Mein Kampf, 151 (my translation).

19 Arnd Bauerkämper, Der Faschismus in Europa (Stuttgart: Reclam, 2006), 178.

$20 \quad$ Bauerkämper, Der Faschismus, 78.
} 


\section{Selecting a Test Case of Non-Hitlerite National Socialism}

The definition of national socialism as a sub-genus of fascism presented above will herein be tested using a case chosen to collide head-on with the prior assumption of mimesis with the German NSDAP. If it can be adequately proven that the Latvian Pèrkonkrusts [Thunder Cross] meets the definition's criteria, then this will be an example of an explicitly anti-German national socialist movement.

Although Pérkonkrusts is not entirely unknown in the literature on fascism, ${ }^{21}$ few scholars have researched this movement in detail. Even fewer still have asked the question whether Pērkonkrusts constitutes a Latvian form of national socialism. ${ }^{22}$ One of the few to do so is German historian Björn Felder. A subchapter to one of his books is even entitled, "The Pérkonkrusts Movement: “Latvian National Socialists"?' While admitting that Pērkonkrusts exhibited many ideological affinities to German National Socialism, in his analysis, Pèrkonkrusts looked more to Italian Fascism for inspiration, or more closely resembled Corneliu Codreanu's Iron Guard in Romania. ${ }^{23}$ During the German occupation of Latvia in the Second World War, Felder describes how one part of the Perkonkrusts movement aligned itself with the German regime, even making ideological concessions to the Nazi racialist worldview. ${ }^{24}$ At the same time, he notes that another part of the movement chose resistance instead, branding the collaborators from their ranks as renegades who shifted their loyalty from Pērkonkrusts leader Gustavs Celmin,š to the German Führer, Hitler. Only those who chose Hitler over Celmiňš, concludes Felder, can rightly be called 'lettische Nationalsozialisten.' ${ }^{25}$ Thus, Felder, too, chooses to equate national socialism with Hitlerism.

Celmiňš also used this same reasoning himself, in an attempt to forestall his movement from being labelled dangerous fifth columnists during the inter-war years of Latvia's independence. At a public discussion on the growing influence of National Socialism in Germany held in Riga in October 1932, the question

21 A sample text from Pērkonkrusts is even included in Griffin's Oxford Reader: Gustavs Celmiņš, 'A Latvian Latvia,' in Fascism, Griffin, 217-218.

22 My first tentative classification of Pērkonkrusts as being national socialist is: Matthew Kott, 'Towards an Uncivil Society: Reactions to Soviet and Nazi Occupation and the Demise of Civil Society in Riga, 1939-1949' (PhD diss., University of Oxford, 2007), 66.

23 Björn M. Felder, Lettland im Zweiten Weltkrieg: Zwischen sowjetischen und deutschen Besatzern 1940-1946 (Paderborn: Schöningh, 2009), 236-237. Arguably, though, Codreanu's Iron Guard also had strong affinities to national socialism.

24 Felder, Lettland, 244.

25 Felder, Lettland, 239. 
was raised as to whether Latvians could - and should - adopt national socialism. ${ }^{26}$ Celmiñš replied in the negative, but ambiguously: the Hitlerbewegung [Hitler movement] developed to suit conditions in Germany. Nevertheless, Latvians could still learn a lesson or two from them: namely, that it is possible to fight the 'international Jewry', and that the working class, at heart, is nationalistic. ${ }^{27}$ What this proves, if anything, is that Perrkonkrusts did not see itself as an appendage or copycat of German National Socialism; at the same time, the ambiguity of these statements can be interpreted as reinforcing the argument that Pèrkonkrusts was national socialist.

Similar rhetorical distancing was used regarding fascism. In an unsigned article from 1933, 'What is fascism?', the party newspaper asserts: 'Even though Pêrkonkrusts is far from being fascism, and admits that this is a system suited only to Italy, nevertheless...'28 By equating fascism exclusively with Italian Fascism, Pêrkonkrusts could deny - despite the charges of its liberal and leftist opponents - that it is, indeed, fascism, while at the same time freely expressing its admiration for the accomplishments of Mussolini's regime. Needless to say, contemporary political opponents were not convinced.

\section{The Fascistogenic Context: Latvia in the 1920s and zos}

Before attempting to discern whether or not Pèrkonkrusts fits the above definition of national socialism, it seems appropriate to summarize the historical context. I have already argued elsewhere that Latvia in the twentieth century was a country where societal conditions promoted political radicalization, and even that during the 1920 s and 1930 s it was a particularly fascistogenic milieu. ${ }^{29}$ Independent Latvia had inherited a multi-ethnic society that was not only in ruins after the First World War, but also riven by class and ethnic tensions. In 1905-1906 and 1919, the country had experienced violent class and ethnic war: class an ethnicity were largely congruent, with the Latvian peasantry and working class aggrieved over the disproportionate economic and political

26 'die Frage, ob man den Nationalsozialismus auf Lettland und das lettische Volk übertragen könne och solle.: 'Diskussionsabend über Hitler im Lettischen Verein,' Rigasche Rundschau, October 14, 1932.

27 Ibid.

28 'Kas ir fašisms?' Pērkonkrusts, June 23,1933.

29 Matthew Kott, "The Roots of Radicalism: Persistent Problems of Class and Ethnicity in Latvia's Politics,' in Latvia - A Work in Progress?: 10o Years of State- and Nation-Building, ed. Matthew Kott and David J. Smith (Stuttgart: Ibidem Verlag, forthcoming). 
power of the Baltic German minority. In the fratricidal civil war following the collapse of the Russian Empire, both Latvian Bolsheviks and Baltic German forces assisted by radicalized Freikorps composed of Reichsdeutsche took turns fighting against the fledgling liberal nationalist Latvian government. The resulting waves of Red Terror and White Terror both exhibited characteristics of genocidal campaigns. ${ }^{30}$ Experiences from Latvia in 1919 helped shape the subsequent German Nazi view of Jewish Bolshevism and Latvians as its willing executioners, ${ }^{31}$ complementing the prior brutal depiction of Latvians in Baltic German accounts of $1905 .{ }^{32}$ Despite the odds, the liberal-democratic Latvian nation state emerged victorious from the civil war. By 1920, thousands of refugees displaced since 1915 were returning. This repatriation included significant numbers of Jews, which contributed to the ethnic diversity of the new polity.

Many ethnic Latvians felt that Latvia was their national state, where their communal interests - for the first time since the conquest by mediaeval German crusaders - should come first. By contrast, many Baltic Germans and Russians of the former ruling gentry could not reconcile themselves to the post-imperial loss of political privilege. Disdain for the language and culture of the Latvian majority was also widespread among them. Nevertheless, this group retained a disproportionate influence over the economy of the country, which caused discontent amongst the new Latvian elites. The opportunities that liberal democracy provided for members of the Jewish to take up highly visible positions in commerce, the professions, and higher education further aggrieved Latvian nationalists.

The political system, with a constitution inspired by that of Weimar Germany, also proved a disappointment to many. The social democrats, the largest group in the Constituent Assembly that had created the political system, most often chose opposition over the responsibility of government. Cabinets cobbled together from too many small parties, all with their own agendas, were consistently short-lived. For example, one hundred and twenty lists of candidates contested the 1928 parliamentary elections, with a record twenty-eight of them gaining representation in the one hundred-seat Saeima. ${ }^{33}$

30 Aldis Minins, 'Latvia, 1918-1920: A Civil War?' Journal of Baltic Studies 46 (2015): 55-57, accessed October 20, 2015, doi: 10.1080/01629778.2015.1009689.

31 Michael Kellogg, The Russian Roots of Nazism: White Émigrés and the Making of National Socialism, 1917-1945 (Cambridge: Cambridge University Press, 2005), 79-102.

32 Particularly influential was: [Astaf von Transehe-Roseneck], Die lettische Revolution (Berlin: Georg Reimer, 1906-1908).

33 Imants Mednis and Māris Antonevičs, 'Politiskās partijas Latvijā', in Latvija divos laikposmos: 1918-1928 un 1991-2001 [Latvia in Two Time Periods], ed. Lubova Zīle (Riga: LV Fonds, 2001), 277-278. A total of 141 lists of candidates were registered for the 1925 elections. 
While allowing for a plurality of political voices in politics, one foreign observer commented that this was 'democracy gone to seed. ${ }^{34}$

Critics on both the left and the right disparaged such politics as corrupt, self-interested horse-trading. Alternatives to democracy were proposed, and rumours of possible coups surfaced periodically. The failed attempt by communists in Tallinn, Estonia, in 1924 proved that these rumours were not entirely without substance. When Prime Minister Kārlis Ulmanis ended parliamentary democracy and introduced an authoritarian regime in Latvia in May 1934, he did so claiming the need to pre-empt an alleged coup planned by the far right.

Already at the very beginning of the 1920s, Latvian Bolshevik leader Pēteris Stučka - who had in 1919 tried to impose his own regime of terror on the country, and now lived in Soviet exile - began to see omens of a rising threat from the antidemocratic, xenophobic, and anti-Semitic far right in Latvia. By 1923, he was already using the term 'fascism', and in 1924-1926 he even suggested that the Latvian communists join with the Social Democrats in a united front to save 'bourgeois' democracy in Latvia. That a sworn enemy of the bourgeoisie like Stučka would even suggest that communists should prop up a liberal democratic system was testimony to how real he thought the possibility of a fascist turn in Latvia was. Neither the Social Democrats in Latvia, nor his own party comrades, however, viewed the political situation in Latvia as being as fascistogenic or menacing as did Stučka. The veteran Bolshevik leader's unorthodox suggestion for common leftist antifascist action thus fell on deaf ears in Riga and in Moscow. ${ }^{35}$

The cause of Stučka's concern was the rise of the first proto-fascist mass movement in Latvia, Latvju nacionālais klubs [LNK; National Club of Latvians]. Already in 1920, a radical nationalist youth organisation was founded, Latviešu nacionālā jaunatnes savienība [LNJs; Union of Latvian National Youth]. This organisation attracted members of the 'front generation', young men who had fought in the national War of Independence, and now expected to be rewarded for their sacrifices by assuming a leading role in the young state. Among the leaders of this movement were Indrikis Pone, Jānis Štelmachers, and Gustavs Celminš - the latter two going on to found competing Latvian national socialist parties in the early 1930s. Already at this time, Štelmachers exhibited his dislike for Jews taking up coveted study places at the University of Latvia.

\footnotetext{
34 Bernard Newman, Baltic Background (London: R. Hale, 1948), 144-145.

35 Leo Gutmanovich Dribin [Leo Dribins], 'P.I. Stuchka: Teoretik i propagandist marksizmaleninizma' (doctoral dissertation, Institut istorii partii pri TsK KP Latvii, Riga, 1983), 345-349. I am indebted to Marina Germane for bringing this source to my attention.
} 
In early 1922, LNJS amalgamated with a competing youth organisation, and its members then disrupted the Social Democrats' Labour Day demonstrations in Riga on 1 May. In the aftermath of the public attention this gained, the LNK was created as an outgrowth of the LNJS, in attempt to broaden the organisation's support beyond university students. Pone assumed the leadership of the new organisation. ${ }^{36}$ For the next two years, the LNK acted as a unifier of the radical right in Latvia, promoting an aggressive Latvian nationalism that was directed against Marxists and national minorities, both of whom were seen as undermining the idea of the Latvian national state. Jews, in particular, were singled out as an enemy: one of the first sections to be formed within the LNK was that devoted to Žìdu iespaida apkarrošanas sekcija [combating Jewish influence]. The purpose of this section was to mobilise Latvian society against the Jews' purported harmful influence over cultural, political, and especially economic life in the country. ${ }^{37}$

Despite gaining sympathisers from across Latvia, the military, and even government officials, the LNK remained primarily a youth organisation concentrated around the University of Latvia. Per Bolin has presented a good overview of the role of the LNK in promoting anti-Semitic policies within the Student Council and University leadership during the $1920{ }^{38}$ The aforementioned communist coup attempt in Tallinn in December 1924 prompted a rapid escalation in the use of violence by members of LNK against their opponents. After two bomb attacks against the Social Democrats' printing press and deadly confrontations with the paramilitary wing of the Social Democratic party, the authorities shut down the LNK on 18 February $1925 \cdot 39$ Although quickly reconstituted as the Latvju nacionālistu klubs [Latvian Nationalists' Club] already in March 1925, after the crackdown the movement's momentum was broken, an the Latvian far right quickly fragmented into a constantly shifting milieu of ephemeral groupuscular organisations.

The LNK remained influential as an idealized symbol, however. Firstly, it was the first Latvian nationalist organisation to promote fascist ideas, ${ }^{40}$ and its

36 Uldis Krēsliṇš, Aktīvais nacionālisms Latvijā 1922-1934 (Riga: Latvijas vēstures institūta apgāds, 2005), 65-67. For a sympathetic treatment, see: Armands Paeglis, Visu par Latviju! Latvju nacionālais klubs un aktīiais nacionālisms 1922-1927 [All for Latvia! The National Club of Latvians and Active Nationalism 1922-1927] (S.l.: the author, 2007).

37 Latvju Nacionālā kluba 1. gads (Riga: Latvju nacionālais klubs, 1924), 23-25.

38 Per Bolin, Between National and Academic Agendas: Ethnic Policies and National Disciplines at the University of Latvia, 1919-1940 (Huddinge: Södertörns högskola, 2012), chapter 5 .

39 Krēslin̄̌š, Aktīivais nacionālisms, 99-100.

$40 \quad$ Krēsliň̦̌, Aktìvais nacionālisms, 67-68. 
first public act was to send a telegram of greeting to Mussolini. ${ }^{41}$ The extent to which the LNK was patterned on the Berliner Nationalklub, which had established a relationship with Hitler's party already by 1921 , is unclear. ${ }^{42}$ Secondly, its early heyday was regarded in retrospect as a period of unity of the Latvian far right, and a number of later movements aspired to re-unite all radical nationalists by claiming to be the true successors to the LNK. Finally, the LNK set several important precedents for later organisations, from the ideological emphasis on anti-Semitism, to outward symbols like the choice of grey shirts as a political uniform. ${ }^{43}$

By the early 1930s, different expressions of national socialism arose in Latvia. In early 1933, the young lawyer Erhard Kroeger, who later led a unit of the ss Einsatzgruppen in occupied Ukraine, tried to register a Baltic German national socialist party. ${ }^{44}$ Prior to this, aforementioned LNJS activist Jānis Štelmachers formed the Apvienotās Latvijas nacionālsociālistu partija [ALNSP; National Socialists' Party of Unified Latvia] already in July $1932 .{ }^{45}$ Predating both of these, however, was Latviešu tautas apvienība 'Ugunskrusts' [Latvian People's Union 'Fire Cross'] founded in January 1932, which later became Pērkonkrusts. ${ }^{46}$ While the former two movements can be (and have been) seen as either an appendage of German Nazism (Kroeger's 'Bewegung'), or a mimetic copycat thereof (Štelmachers's ALNSP) ${ }^{47}$ the same is not easily said of the latter.

41 Reproduced in: Krēsliṇš, Aktīvais nacionālisms, 92.

42 Ibid., 67.

43 On the use of grey shirts by the LNK, see: Paeglis, Visu par Latviju, 118, 398.

44 Matthias Schröder, Deutschbaltische ss-Führer und Andrej Vlasov 1942-1945: 'Rußland kann nur von Russen besiegt werden': Erhard Kroeger, Friedrich Buchardt und die 'Russische Befreiungsarmee' (Paderborn: Schöningh, 2001), 29-30.

45 Krēsliň̦̌, Aktīvais nacionālisms, 145.

$46 \quad$ Ibid., 142.

47 Regarding ALnsp, Krēsliṇš stresses that national socialism 'is and remains an import [importa produkts]' supported by a revisionist foreign power, i.e. Nazi Germany: Ibid., 145 . See also Andres Kasekamp, The Radical Right in Interwar Estonia (Basingstoke: Macmillan, 200o), 144. Regarding Kroeger's movement, even Schröder adopts a teleological interpretation based on the fact that Kroeger's movement did become a local branch organisation of Nazi regime in Germany: Schröder, Deutschbaltische ss-Führer. At the same time, Gottlob Berger points out in 1943 that Kroeger had been in volunteer or honorary (ehrenamtlich) service with the SD since 1934: Berger to Brandt, 22 Oct. 1943, BundesarchivBerlin (BArch), sso-Akt Erhard Kroeger, frame 826. This does not necessarily mean, however, one should assume that Baltic German national socialism was from the beginning intended to be just Hitlerism in Latvia. Indeed, both various writings of Kroeger, plus Himmler's wartime complaints that Baltic Germans have their own political agenda suggest that local Baltic German interpretations of national socialism may have persisted 
Despite the movement using a swastika (Latvian: ugunskrusts) as its emblem, it was more properly a development of the directions set out by the LNK, than a reaction to the rise of the NSDAP in Germany.

\section{Gustavs Celmiṇš and the Development of Pērkonkrusts}

The story of Pērkonkrusts inextricably linked to that of its leader, Celmiňš. He was born in Riga in 1899. During th First World War his school was evacuated to Moscow, where he remained until the Bolshevik Revolution. He took part in the Latvian War of Independence in the Student Company, for which he was awarded the Order of Lāčplēsis, independent Latvia's highest military honour. He was thus a member of the Latvian 'front generation' that had fought both enemies of Latvian self-determination: Stučka's Bolsheviks and the imperialistic alliance of Baltic Germans and the Freikorps. ${ }^{48}$

Like many independence veterans, Celminš combined a career in the new state's civil service with university studies. He became involved in student politics and was elected to the Student Council from the nationalistic fraternities' list as a nominee from his fraternity, Selonija. Despite this, there was little ideological difference between him and fellow student leaders like Pone, elected from the LNK platform. In this way, various LNK activists could dominate the student political scene. After the LNK went into decline, Celmiňš remained prominent in student politics, establishing himself as an ideologue of the fraternities milieu, particularly after a 1925 article in the daily, Rigas Zinas, outlining the key role of students in the nationalist movement. ${ }^{49} \mathrm{He}$ proceeded to seek a greater role in state politics, joining the Nacionālà apvienība [National Alliance] of Arveds Bergs, the doyen of Latvian national conservatism and 'intellectual' anti-Semitism. ${ }^{50}$ Despite quickly rising to a prominent role in the

well into the Second World War: e.g. Verwendung von Emigranten als Dolmetscher, 21 April 1942, BArch, NS 19/3514/106.

48 'Gustavs Celmin̦š', in Lāčplēša Kara ordeña kavalieri: Biogräfiska vārdnīca [Holders of the Lāčplēšis Military Order: Biographical Dictionary], M. Šēnbergs et al. (Riga: Latvijas Valsts vēstures arhīvs; Jān,a seta, 1995), 112. Celmiņš̌s commendation for the Lāčplēsis Order was for gallantry in battle with Bolshevik forces on March 4, 1919: Armands Paeglis, Pērkonkrusts pār Latviju 1932-1944 (Riga: Klubs 415, 2005), 47.

49 Gustavs Celmin̦š, 'Latvju studenti krustcel̦os,' Rigas Zinas, 8 August 1925. For the characterization as an ideologue of the fraternities membership based on this article, see: 'Skats studentu dzīvē,' Centra Balss, 5 April 1929.

50 Valdis O. Lumans, Latvia in World War II (New York: Fordham University Press, 2006), 221-222. 
National Alliance, Celmin̦š nevertheless became disillusioned with Bergs's lack of radicalism. When he failed to win a parliamentary seat in the November 1931 elections due to the poor results for the National Alliance, Celminš was determined instead to build a more activist movement for the ultranationalist struggle..$^{51}$

The initial initiative to bring together LNK activists seems to have been that of fellow Selonija member Jānis Greble, but Celmiņš soon established himself as the leader of what he envisioned as an cinnas organizācija [organisation for the struggle] by the time Ugunskrusts was officially founded in January 1932. The group brought together young men from the various overlapping nationalist milieux: the former LNK and LNJS; the fraternities; the National Alliance and Bergs's newspaper Latvis [The Lett]; and the sports and 'moral and physical training' club Tevijas sargi [Fatherland Guards]. ${ }^{52}$ The inheritance of the LNK was claimed by adopting the grey shirt as the new movement's uniform.

Ugunskrusts existed for about a year, until it was shut down by parliamentary decree in April 1933. This eventuality was apparently foreseen, since the movement also co-opted the moribund Tèvijas sargi, headed by Ugunskrusts member and Baltic linguistics professor Juris Plākis, as a way of continuing operations in the face of a clampdown. ${ }^{53}$ Tèvijas sargi thus served as a bridge organisation until the party re-registered, now under the name Pērkonkrusts, in May that year. Perrkonkrusts continued to operate openly until the coup by Ulmanis in May 1934, when it and Tèvijas sargi were banned for allegedly preparing their own coup.

Even though there is no evidence to suggest that Pērkonkrusts was preparing a violent takeover of power, ${ }^{54}$ the Ulmanis regime arrested Celminš and other leaders of Pèrkonkrusts, who were tried and sentenced to imprisonment for periods ranging from four months to three years. In all, 128 Pérkonkrusts members were arrested in $1934 .{ }^{55}$ Unlike Bergs, who applauded the 'long-awaited' advent of a nationalist-patriarchal authoritarian regime, ${ }^{56}$ Pērkonkrusts was

\footnotetext{
$51 \quad$ Paeglis, Pērkonkrusts, 11-12.

52 Ibid.; Krēsliṇ̌s, Aktīvais nacionālisms, 142-143.

53 Paeglis, Pērkonkrusts, 30-33.

54 Valters Ščerbinskis, '1934. gada 15. maija apvērsums: cēloṇi, norise un sekas', in Apvērsums: 1934. gada 15. maija notikumi avotos un pètījumos [Coup d'état: The Events of 15 May 1934 in Primary Sources and Research Findings], ed. Valters Ščerbinskis and Ēriks Jēkabsons (Riga: Latvijas Nacionālais arhīvs; Latvijas arhīvistu biedrība, 2012), 34-35.

55 Ščerbinskis, '1934. gada 15. maija apvērsums', 45-46. Also arrested were 503 Social Democrats and Bundists, 126 Communists, as well as smaller numbers of other activists from political and ethnic minority organisations.

$5^{6}$ Sčerbinskis, '1934. gada 15. maija apvērsums', 31.
} 
negative. Celmiňš accused Ulmanis of plagiarizing his party's slogan of a 'Latvian Latvia', while not having the vision for the radical reorganisation of society of Perkonkrusts. The party had no intention of collaborating with the Ulmanis regime, and went underground. ${ }^{57}$ Attempts to mediate between Ulmanis, Celmiñš, and Bergs to find a common ground, begun already before the coup, failed due to the parties' vastly different worldviews. ${ }^{58}$

After serving his prison sentence, Celmiňš went into exile abroad. Based in Italy, he also visited Poland, Hungary, Romania, Yugoslavia, Turkey, Germany, and Estonia. ${ }^{59}$ During this time he met intensively with other fascists, including travelling to Romania to meet Codreanu and discussing the creation of an international network based in Switzerland. ${ }^{60}$ In Zürich in 1938 he gave a lecture for the national socialist Nationale Front, and an article on Pērkonkrusts appeared in the party newspaper, Die Front. Celmin,š felt that Pérkonkrusts had strong affinities to both the Nationale Front and the Iron Guard. According to Latvian political police sources, Celmiňš even developed contacts with certain circles within German National Socialism, but he rejected an offer of financial support, so as to retain independence. ${ }^{61}$ In late 1938 , Celmiňs moved to Finland, where his connections to Marshal Gustaf Mannerheim led to him being made adjutant to Captain Bertil Nordlund, commander of Detachment Sisu for foreign volunteers during the Finnish-Soviet Winter War. ${ }^{62}$

In the meantime, the Pērkonkrusts underground in Latvia continued to be a concern for the authorities of the Ulmanis regime. Led by Ernests Plākis (son of J. Plāḳis) during Celmiṇšss exile, they continued their clandestine subversive

57 Paeglis, Pērkonkrusts, 86-89.

$5^{8}$ Sčerbinskis, '1934. gada 15. maija apvērsums', 31; Jürgen von Hehn, Lettland zwischen Demokratie und Diktatur: Zur Geschichte des lettländischen Staatsstreichs vom 15. Mai 1934 (Munich: Isar, 1957), 49.

59 Paeglis, Pērkonkrusts, 147.

6o Kasekamp, The Radical Right, 147. Ëriks Jēkabsons describes Codreanu as having been a 'personal friend' of Celminšs: Ėriks Jēkabsons, 'Pre-World War II Romania from Latvian Perspective: An Envoy's Views,' Revista Română de Studii Baltice şi Nordice 3 (2011): 164.

61 Paeglis, Pērkonkrusts, 10, 139. Kārlis Kangeris suggests there were also contacts with the NSDAP-Landsgruppe in Latvia from 1938: Kārlis Kangeris, 'Kollaboration vor der Kollaboration?: Die baltische Emigranten und ihre "Befreiungskomittees" in Deutschland 1940/1941,' in Europa unterm Hakenkreuz: Okkupation und Kollaboration (1938-1945): Beiträge zu Konzepten und Praxis der Kollaboration in der deutschen Okkupationspolitik, ed. Werner Roehr (Berlin: Hüthig 1994), 172 footnote 29.

62 Paeglis, Pērkonkrusts, 148; Gustavs Celmin̦š, 'Mūs apmeklē maršals Mannerheims [Marshal Mannerheim Comes to Visit],' Daugavas Vēstnesis, 18 June 1942. Some sources say Celmiṇš was an honorary adjutant to Mannerheim: 'Gustavs Celmiňš', 112. Other sources refer to his second wife, Hagar Veltheim, as being his connection to the circle around Mannerheim. 
activities of resistance by distributing anti-Ulmanis leaflets and attempting to infiltrate the armed forces and paramilitary Aizsargi [Home Guard]. ${ }^{63}$ Even Soviet intelligence knew of these activities and speculated that the son of President Alberts Kviesis, whom Ulmanis illegally succeeded in 1936, was also sympathetic to Pérkonkruksts. ${ }^{64}$ The authorities in Latvia continued to persecute and arrest Pérkonkrusts activists both under the Ulmanis regime, and later under the Soviets in $1940-41$, as well. ${ }^{65}$

\section{The Pērkonkrusts Ideology: Palingenetic Völksich Racialism or Not?}

To what extent was Pêrkonkrusts national socialist, that is, a type of fascism where the populist ultranationalism is based on palingenetic völkisch racism, of which anti-Semitism is an essential element? One of the first problems to address is whether Pêrkonkrusts had a racist ideology, and whether it was völkisch. Did, for example, Pêrkonkrusts contrast the Aryan race to the Jewish one in its worldview? Historian Uldis Krēsliņš contrasts Pērkonkrusts with Štelmachers's ALNSP, which proclaimed Latvians to be the 'purest' Aryans, by citing a passage from a speech where Celmiňš dismisses the idea of 'biologically pure' Latvians, since 'a pure Latvian type does not even exist [nemaz nav]'. For Krēsliņš, with the exception of Štelmachers, the racial terminology employed by Pērkonkrusts and other Latvian radical nationalists was 'more an expression of an historical, religious, or moral-ethical' signifier. ${ }^{66}$

The problem is that Krēsliņš does not quote Celmiñš in full: directly after denying the contemporary existence of pure Latvians, he says that a pure Latvian is possible in the future, if the nation were to be painstakingly cleansed of foreign elements. Since the future existence of the Latvian nation depends on the success of this long and complex process, Pērkonkrusts would work

63 Paeglis, Pērkonkrusts, 120-137. Attempts to woo members of the Aizsargi began already earlier, since Celmin,š himself had been a company commander in the Aizsargi: Ilgvars Butulis, Sveiki, Aizsargi! Aizsargu organizācija Latvijas sabiedrības politiskajā dzīvē 1919.1940. gadā [Hail, Aizsargi! The Aizsargi Organisation in the Political Life of Latvian Society, 1919-1940] (Riga: Jumava, 2011), 65.

64 L. F. Sotskov, ed., Pribaltika i geopolitika 1935-1945. gg.: Rassekrechnye dokumenty Sluzhby vneshneirazvedki Rossiiskoi Federatsii [The Baltics and Geopolitics, 1935-1945: Declassified Documents of the Foreign Intelligence Service of the Russian Federation] (Moscow: RIPOL Klassik, 2009), 35 .

65 Andrievs Ezergailis, Holokausts vācu okupētajā Latvijā 1941-1944 (Riga: Latvijas Vēstures institūta apgāds, 1999), 104.

66 Krēslinšs, Aktīvais nacionālisms, 207. 
toward this goal, step by step, 'broadly, systematically [plaši, sistemātiski]'.67 Elsewhere, this sentiment is reiterated by the deputy leader of Pérkonkrusts, Prof. J. Plākis: after discussing the negative influence of secret organisations controlled by the Jews, it was stressed that 'only by keeping our race pure, protecting and maintaining our people's traits and traditions, can Latvians persist as a people' ${ }^{68}$ This was clearly a palingenetic racialist nationalism.

In contrast to what Krēsliņš claims above, the Pērkonkrusts discourse on Jews as a race was not merely on the level of symbol or abstraction. Instead, there was a very concrete expression of the struggle between Jewish race and its opponents for survival. While occasionally couched in terms of a struggle between the 'Semitic' and 'white' races, ${ }^{69}$ the usual dichotomy employed is 'Jews' versus 'Aryans. ${ }^{70}$ A formulation from the 1933 article, 'Who Are the Latvians of Pèrkonkrusts', is immediately recognizable as belonging to the ideological worldview of national socialism: 'In addition, one must particularly mention those tendencies created by Jews to conquer the world and destroy nationalism and the Aryan peoples. ${ }^{71}$ Just prior to the riots in Paris associated with the Stavisky Affair in 1934, Pêrkonkrusts's newspaper quoted at length the prominent Francist Henry Coston from Le Libre Parole, including the claim that the next global conflict unleashed by the Jews would result in 'the murder of 15 million Aryans and, for those who escape murder, Bolshevisation, i.e. slavery.72 This contradistinction between Jews and Aryans could even take improbable forms: for example, when an editorial in Ugunskrusts explained that, of course, the Germans wanted to turn Latvia into a colony with the Latvians as their minions, but, being Aryans, at least they were forthright in this; Jews, on the other hand, were disingenuous and surreptitious in their plans to subjugate other peoples. ${ }^{73}$

Furthermore, the Perrkonkrusts party press clearly identified the Latvians' ancient forebears, the Baltic tribes, with the primeval Aryans, particularly in context of discussions of the neopagan religion of Ernests Brastiňš, Dievturība. ${ }^{74}$

67 Gustavs Celmiṇš, 'Latvijas kerenščina ar oktobra revolūciju nenoslēgsies - par to gādās Pērkonkrusts,' [Kerenskyism in Latvia will not end in an October Revolution-Pērkonkrusts will see to that] Pērkonkrusts, 24 September 1933.

68 'Pērkonkrustieši Latgalē,' Pērkonkrusts, 15 October 1933.

69 'Kamdēl žīdi visur un vienmēr ir tikuši nīsti?' Pērkonkrusts, 21 May 1933.

$70 \quad$ Or even 'Semitic' and 'Aryan' races: “'Nejaušǐba...”,' Ugunskrusts, 8 January 1933.

71 'Kas ir Pērkonkrusta latvieši,' Pērkonkrusts, 18 June 1933.

72 'Izraēlis grib kaŗu!' Pērkonkrusts, 27 January 1934. Emphasis in original.

73 'Žìdi vai vācieši?' Ugunskrusts, 30 October 1932. Also in: Ezergailis, Holokausts, 103.

74 The Dievturi, as they called themselves, were closely associated with Pērkonkrusts circles, even if they were not always members: Krēslin̦š, Aktīvais nacionālisms, 229; Ezergailis, 
An article in Ugunskrusts on Dievturība reports Brastinšs's view that the Germanic, Slavic, Baltic, and Indic peoples arose from the original Aryans, and that the Latvians are the direct descendants of the Aryans in their language and religious worldview. ${ }^{75}$ It was a divine mission to 'renew the Aryan Latvian religion [atjaunot āriskilatvisko reliǵiju], in order to restore it to Aryan Europe. ${ }^{76}$ Another context where the Baltic-Aryan connection appeared was in the description of the historical conditions that have shaped the unique Latvian character, and the role this has for the destiny of the Latvians: the 1934 article, 'The Blood of the Ancestors Begins to Speak', asks how the Latvian people will earn a place in the future Aryan family of nations: 'What did you do, while the rest of the Aryan peoples were fighting for their rights of primogeniture on the globe?'77

Thus, from its very beginnings, Perrkonkrusts was infused with an intrinsically racialist worldview that fits well with the definition of national socialist völkisch racialism. Völkisch ultranationalism, however, is not only about the Aryan 'blood'; there is also the sacralization of the relationship to the 'soil'. The Latvian land, saturated in the sweat and blood of the forefathers, was sacred: it was here their heroic ancient forebears fought; here their ancestors' remains are buried. None is more closely entwined with the beloved landscape than the Latvian aräjs - 'ploughman'.78 The official party programme of Pêrkonkrusts already lists as its second point: 'Latvia is and shall remain an agricultural country. Its economic policy should conform solely to this rule.' The state should actively support and develop agriculture, while limiting and controlling industrialisation. ${ }^{79}$

Holokausts, 104. Some sources include Brastinš as one of those brought together by Greble in the founding phase of Ugunskrusts: Paeglis, Pêrkonkrusts, 10. The choice of the swastika as party emblem was on the suggestion of Brastinš: Ezergailis, Holokausts, 102. For an indepth study of the role of neopaganism as a catalyst for non-German national socialism in Norway, see: Terje Emberland, Religion og rase: Nyhedenskap og nazisme i Norge 1933-1945 (Oslo: Humanist, 2003).

75 'Kas îsti ir Brastina dievturība?' Ugunskrusts, 2 October 1932. This latter idea would recur in Pērkonkrusts publications: Ārija, 'Āriešu ticība,' Pērkonkrusts, ${ }_{15}$ October 1933; 'Latviskais tikumības jēdziens dainās,' Pērkonkrusts, 22 October 1933.

76 'Kas īsti'. Krēslin̦š asserts that this mission was embraced by Pērkonkrusts as its own: Krēsliṇš, Aktīvais nacionālisms, 229.

77 'Senču asinis sāk runāt,' Pērkonkrusts, 20 January 1934.

78 'Jauns cīnas gads sākas! [A New Year of Struggle Begins!]' Ugunskrusts, 1 January 1933.

79 'Latviešu Tautas Apvienības "Pērkonkrusts" apstiprinātā programma, [Official Programme of the Latvian People's Union 'Pērkonkrusts']' reproduced in: Paeglis, Pērkonkrusts, 197-198. 
The goal of Pêrkonkrusts was a national regeneration of the national socialist type. Indeed, Celmiňs noted retrospectively in January 1942 that, in the 1930s, 'every racially healthy and nationally aware Latvian' could see the decadence of the parliamentary system and the permissive societal structures that created the need for Perkonkrusts. ${ }^{80}$ As intimated by Celminš in the speech quoted previously, this would require proper application racial hygiene. For example, in October 1932, internal propaganda courses were held on the topic of rāsu izlase [racial selection]. ${ }^{81}$ The enactment of the abortion legislation in 1933 was roundly condemned as 'legalized debauchery', because allegedly it gave private medical practitioners - i.e. Jewish doctors motivated by profit free hands to decide eugenic procedures that could negatively affect the birthrate of Latvians. Pèrkonkrusts promised to dutifully protect 'our race' [savu rasi] from this. ${ }^{82}$ At the same time, in the public debate on sterilisation legislation (finally enacted in 1937), Pērkonkrusts was vocally in favour of laws that would target not only the physically or mentally disabled, but also criminals and 'Jews, Negroes, Mongols, and other such' persons. ${ }^{83}$ Central in formulating the stance of Pérkonkrusts on eugenic issues were psychiatrists E. Plākis and Hermanis Saltups. ${ }^{84}$

Nevertheless, this racialism is tempered by nationalism: "The Latvian nation is our faith, the boundary of our understanding of race. ${ }^{85}$ Latvians in the southeast of the country that had over the generations opted to identify as Poles or Belarusians would need to be won back to the nation; ${ }^{86}$ this was part of the campaign to regain ground 'everywhere the Latvian language is or has been heard': 87 The goal was a Latvian Latvia in the traditional of the ethnic Latvians, 'where the question of minorities [would] not exist [nemaz nebūs]'.88 The two main minorities targeted by Pèrkonkrusts were the Baltic Germans and the Jews: the former, as descendants of the Teutonic Knights, represented the historical

\footnotetext{
8o Paeglis, Pērkonkrusts, 59 .

$81 \quad$ Ugunskrusts, 23 October 1932.

82 'Legalizēta izvirtība, [Legalised Debauchery]' Pērkonkrusts, 24 September 1933.

83 'Vārds latviešu ārstiem-zinātniekiem un likumdevējiem, [A Word to Latvian Medical Scientists and Legislators]' Pērkonkrusts, 4June 1933.

84 Felder, Lettland, 293.

85 'Vai mūsu vārdi CĪN̦U SĀKOT nav piepildījušies? [Have Not Our Words from 'Starting the Struggle' Been Fulfilled?]' Pērkonkrusts, 20 August 1933.

86 Celmiňš, 'Latvijas kerenščina'; 'Pērkonkrustieši Latgalē'.

87 Kas ir? Ko grib? Kā darbojas? Pērkonkrusts [Pērkonkrusts: What Is It? What Does It Want? How Does it Work?] (Riga: LTA Pērkonkrusts, 1933), 11, reproduced in: Paeglis, Pērkonkrusts, 185 .

88 Celmin̦š, 'Latvijas kerenščina'. Cf. Celmin̦š, 'A Latvian Latvia,' 218.
} 
foes of Latvian national aspirations, while the latter represented the forces of degenerative modernity. ${ }^{89}$ Echoing the later ethno-pluralism of Alain de Benoist, Celmiňš says that 'non-Latvians' - Germans, Poles, Russians, and Jews (sic) - have their own homelands, so they should leave the territory of Latvia to the Latvians. Interestingly, neither Estonians nor Lithuanians are to be considered 'foreign nationalities' in the Latvian Latvia envisioned by Perrkonkrusts. ${ }^{90}$ Even if these neighbouring peoples may be considered somehow part of a common Baltic Schicksalsgemeinschaft together with Latvians, the implications of this non-foreigner status is not fully developed by Celmins.s. ${ }^{91}$ On the other hand, political, economic, and military savienība [union] with the Baltic states was to be the foundation of a Latvian Latvia's foreign policy according to the party programme ${ }^{92}$ During the Second World War, Celminš expanded this to the idea of a possible Nordic-Baltic bloc together with Finland and Sweden. ${ }^{93}$

Contrary to the assertion by Krēslinš that Romanis conspicuously were not singled out as enemies by the inter-war Latvian radical right, ${ }^{94}$ there are several instances of 'Gypsies' being named as hostile foreign elements in the Pērkonkrusts press, usually in conjunction with Jews, ${ }^{95}$ and including perpetuating antiziganistic stereotypes of cheating, thieving parasites. ${ }^{96}$

Due to the role that members of the movement subsequently played during the Holocaust, there has been some discussion of whether or not the racialist palingenetic ultranationalism of Perkonkrusts was also eliminationist, i.e. teleologically geared towards genocide. Historian Andrew Ezergailis has referred in his monograph on the Holocaust in occupied Latvia to an article already quoted above, which closes by saying: 'We have never, do not, nor ever will incite to violence against foreign nationalities [sveštautiešu graušanu]. We only want to put them in their proper place in our country. ${ }^{97}$ In the aforementioned speech from 1933, Celmiňš elaborates how a Latvia without non-Latvians will be

\footnotetext{
89 Paeglis, Pērkonkrusts, 22.

90 Celmiṇš, 'Latvijas kerenščina'. Cf. Krēsliṇš, Aktīvais nacionālisms, 202.

91 Paeglis, Pērkonkrusts, 21.

92 'Latviešu Tautas Apvienības "Pērkonkrusts" apstiprinātā programma,' reproduced in: Paeglis, Pērkonkrusts, 197.

93 See, for example, the SD's translation of Brīvā Latvija no. 7 (Nov. 1943), where Celmiṇš describes his vision of a future Latvia in a Nordic-Baltic bloc: Latvijas Nacionālais arhīvs Latvijas Valsts vēstures arhīvs (LNA LVVA), P-252. fonds, 1. apraksts, 26. lieta, 96.-104. lapas.

94 Krēsliṇ̌s, Aktīvais nacionālisms, 202.

95 E.g. Induls, 'Latvija mostas!' Ugunskrusts, 2 October 1932; 'Dienas ainas,' Ugunskrusts, 12 February 1933;'Latvju zeme runā,' Pērkonkrusts, 8 October 1933.

96 Valdis (V. Zālītis), 'Kurzeme', Ugunskrusts, 8 February 1933.

97 Ezergailis, Holokausts, 104. Original article: 'Žīdi vai vācieši?'. Cf. Paeglis, Pērkonkrusts, 21.
} 
achieved: not by 'physical destruction' as the 'Jews do to Russians' in Soviet Russia, since hatred on the basis of ethnicity alone was supposedly alien to Pērkonkrusts. Nevertheless, without going into details, Celminšs states that there are 'many and varied ways to achieve the same thing. Gradually and according to a specific plan we will deprive non-Latvians of their political rights and possibilities to exist [eksistences iespejjamības]. ${ }^{98}$ From his Finnish exile in 1938, Celminšs wrote to his followers in Latvia: 'Europe and the entire world are on the eve of a great and deep reorganisation, the beginning of a new era.... This time the fate of the Jews in Europe will be decided fully and radically, when the new era has been established, there will no longer be a single Jew in the countries of Europe. ${ }^{99}$ While not directly inciting ethnic violence, the eliminationist mind-set in the name of purifying the nation is already evident from an early stage.

\section{Anti-German National Socialists: Pērkonkrusts during the German Occupation}

Thus, despite its pronounced anti-(Baltic) German position that also included suspicion of the expansionist aims of Hilterism in Germany, ${ }^{100}$ Pērkonkrusts fits well ideologically with the definition of generic national socialism proposed at the outset. By allowing for Perrkonkrusts to be anti-German national socialists, it is possible to better understand the otherwise paradoxical behaviour of Celminš and his party comrades during the German occupation and the Holocaust, which seemingly mixed elements of both collaboration in genocide with political acts of resistance.

As mentioned above, Celmiňš began cultivating connections with the Nazi regime in Germany around 1939, seeking to be acknowledged as the leader of a national socialist movement. ${ }^{101}$ Following the end of the Winter War and the occupation of Latvia by the USSR, Celmiňš moved to Berlin with the aid of the NSDAP representation in Finland. In early 1941, he was joined there by other Pērkonkrusts members Evalds Andersons, Edmunds Puksis, and Arvīds Melliňs. Pérkonkrusts by this time had contacts within the SD and the German

\footnotetext{
98 Celmiņš, 'Latvijas kerenščina’.

99 Quoted in Daina Bleiere et al., Latvija Otrajā pasaules karā (1939-1945) [Latvia in World War II (1939-1945)] (Riga: Jumava, 2008), 106. Katrin Reichelt, Lettland unter deutscher Besatzung 1941-1944: Der lettische Anteil am Holocaust (Berlin: Metropol, 2011), 50-51.

100 E.g. 'Esiet nomodā par savu dzimto zemi!' Pērkonkrusts, 15 October 1933.

101 Paeglis, Pērkonkrusts, 139.
} 
armed forces, and were to return to Latvia in late June 1941 as Sonderführer embedded with the Wehrmacht. ${ }^{102}$ Back in Riga by early July, Celminš was intimately involved in an attempt by various nationalist figures to get the Germans to back Latvian independence; Valdis Lumans characterizes his actions at this time as aspiring to become Latvia's Vidkun Quisling. ${ }^{103}$ Although Celminš was outmanoeuvred by rival political actors during his failed attempt to lobby for Latvian independence with Hitler in Berlin, ${ }^{104}$ in the early days of the German occupation of Latvia, Perrkonkrusts activists sought to ensconce themselves in all manner of positions of power and influence, but particularly those of perennial interest to national socialists: military and youth matters, ${ }^{105}$ but also cultural and labour affairs. ${ }^{106}$ They were aided in this by the fact that, for a brief period before being shut down again by the German authorities on 17 August 1941, Pérkonkrusts was the only Latvian political organisation allowed to function openly. In a number of cities and towns around the country, Pērkonkrusts activists established themselves in posts with control over municipal authorities, the police, or the local press. ${ }^{107}$ One new institution that Pèrkonkrusts activists helped found and develop was the Institute of Anti-Semitism in Riga, whose contribution was the intensification and dissemination of virulent anti-Semitic propaganda. ${ }^{108}$ According to Katrin Reichelt, Prof. J. Plāḳis even organised a seminar for antiSemitic research at the University of Latvia. ${ }^{109}$ Members of Pērkonkrusts along with students, officers, aizsargi, and any other 'nationally-minded Latvians' - were also openly encouraged to join the notorious murder squads being formed in July 1941 by the SD under the leadership of Viktors Arājs. ${ }^{110}$ As a result, members of Perrkonkrusts exerted a disproportionate influence on the course of the Holocaust in Latvia, even though their proportion amongst

\footnotetext{
102 Felder, Lettland, 232-233; Paeglis, Pērkonkrusts, 150.

103 Lumans, Latvia, 161.

104 According to Felder, Hitler, Himmler and other leaders of the NSDAP could not view Pērkonkrusts as national socialists due to their Germanocentric prejudices: Felder, Lettland, 245 .

105 Paeglis, Pērkonkrusts, 151.

106 Felder, Lettland, 240.

107 Ibid., 242-243.

108 Ibid., 243-244; Kaspars Zellis, Ilūziju un baiļu mašinērija: Propaganda nacistu okupētajā Latvijā: Vara, mediji un sabiedrïba (1941-1945)[The Machinery of Illusions and Fear: Propaganda in Nazi-Occupied Latvia - Power, the Media, and Society (1941-1945)] (Riga: Mansards 2012), 66-67;

109 Reichelt, Lettland, 269.

110 'Uzaicinājums,' Tēvija, 4July 1941.
} 
the actual perpetrators of murder have at times been exaggerated, ${ }_{111}^{11}$ particularly in the Soviet narrative of events. ${ }^{112}$

Even though the elimination of the Jews from Latvia was a policy where Pêrkonkrusts could find much common ground with the German Nazi occupation regime, their long-term goal of a Latvian Latvia remained. As such, the various forms of collaboration by members of Pērkonkrusts were clearly tactical, while their activities that can be categorized as resistance are more strategic. Even the German officials understood that Pèrkonkrusts was a force that had its own policy goals: 'They like to call themselves Latvian national socialists, which gives the impression that they are the given choice as intermediaries for the German leadership. But one must never forget that, until 1940, they with their slogan "Latvia for Latvians" sought the removal of both Jews and Germans from Latvia.'113

Following the renewed ban on their organisation, the activities of the membership split into several directions. Some served in the Sonderkommado Arājs, while others withdrew from the public sphere. A number went into active resistance, which was a return to their familiar clandestine state since 1934. ${ }^{114}$ Yet several prominent members outwardly collaborated with the occupation regime: Âdolfs Šilde became a leading member of the Tautas palìdzība organisation [Popular Relief], connected to the German Nationalsozialistische Volkswohlfahrt and Winterhilfswerk;115 Puksis was briefly Director of the collaborationist Culture Department; Andersons became Deputy Director of the Department of Labour. ${ }^{116}$ E. Plākis, Saltups,

111 Reichelt, Lettland, 362; Rudīte Vīksne, 'Members of the Arājs Commando in Soviet Court Files: Social Position, Education, Reasons for Volunteering, Penalty,' in The Hidden and Forbidden History of Latvia under Soviet and Nazi Occupations 1940-1991: Selected Research of the Commission of the Historians of Latvia, ed. Valters Nollendorfs and Erwin Oberländer (Riga: Institute of the History of Latvia, 2005), 188.

112 E.g. in the postwar Soviet interrogation of Alfrēds Vītin̦š, in: A.R. Diukov et al., ed., 'Unichtozhit' kak mozhno bol'she...': Latviiskie kollaboratsionistskie formirovaniia na territorii Belorussii, 1942-1944 gg. Sbornik dokumentov ['Destroy as Many as Possible...': Latvian Collaborationist Formations on the Territory of Belarus, 1942-1944 - A Collection of Documents] (Moscow: Fond istoricheskaia pamiat, 2009), 309. Some post-Soviet Russian narratives even claim that Arājs himself was a member of Pērkonkrusts, e.g.: Mikhail Krysin, Pribaltiiskii fashizm: Istoriia i sovremennost' (Moscow: Veche, 2007), 183.

113 Report of Regierungsrat Friedrich Trampedach, 16 August 1941, quoted in: Reichelt, Lettland, 298.

114 Felder, Lettland, 293.

115 Kott, 'Towards an Uncivil Society,' 180.

116 Felder, Lettland, 240. 
and others worked for the Department of Health. ${ }^{117}$ These areas are not necessarily chosen by chance; instead they very directly correspond to the policy interests of Pèrkonkrusts: youth and family, labour, culture, eugenics. The infiltration of these institutions was thus a way of trying to subvert the Nazi occupation regime for Pērkonkrusts own ends.

Nowhere is this more evident in the examples of Celminšs's own career under the Germans, and the so-called Lettische Kartei [Latvian Card-Index]. From late 1941, Celminš headed the recruitment centre for the Latvian Schutzmannschaften, militarized police auxiliaries on the pattern of German Ordnungspolizei battalions. ${ }^{118}$ Instead of being an encouragement for Latvians to serve as cannon fodder in German uniform, the motivation for this was to get as many Latvian men under arms as possible, in hopes of forming a new Latvian army. Similar to Vidkun Quisling, Anton Mussert, and other national socialists in Axis-controlled Europe, Celmiňš had approached Himmler already in July 1941 with the idea of an autonomous Latvian Volunteer Legion under the ideological control of Pērkonkrusts. ${ }^{119}$ In time, however, Celmiņš understood this was not to be, and was removed from his post in 1943 for actively dissuading Latvians from enlisting. ${ }^{120}$ Celminsš managed to retain a post as translator in the Department of the Interior, giving him access to confidential information, which he was able to pass on to his networks that were producing underground anti-German newspapers. In March 1944, Celmiňš and several other Pérkonkrusts activists were arrested by the Gestapo for resistance activities. ${ }^{121}$

The other example is the Lettische Kartei. This was a small group of Latvians led by Felikss Rikards, based on a clandestine Pērkonkrusts resistance network built up during the Soviet occupation in 1940-1941. This group emerged to collaborate with the German SD and Security Police, functioning as a kind of intelligence operation for both the Germans and the collaborationist Latvian apparatus. The Germans initially granted the group - also known as Sonderkommando $R$ (for 'Rikards') - a certain autonomy, allowing Celmiňš to steer the ideological direction of the group's intelligence gathering on 'disloyal'

117 Ibid., 293.

118 Ibid., 271. The similar to other such units recruited in the occupied eastern territories, Latvian Schuma battalions were involved in various atrocities in Latvia and elsewhere.

119 Ibid., 269. On the Germanic Legions, see: Emberland and Kott, Himmlers Norge, 262-263.

120 Kott, 'Towards an Uncivil Society,' 193.

121 Ibid.; Paeglis, Pērkonkrusts, 152. Celmiņš ended up in Flossenbürg concentration camp along with, amongst others, the Austrofascist leader, Kurt Schuschnigg. He was later liberated by American forces in Italy: Gustavs Celmin̦š, Eiropas krustcel,os [At the Crossroads of Europe] (Esslingen: Dzintarzeme, 1947). 
individuals. This Pērkonkrusts-dominated outfit was able to operate independently until 1943, when it was absorbed into the German Security Police structures. Thereafter many of its former members engaged in anti-German resistance. ${ }^{122}$

Operating in this uneasy symbiosis with the German Nazi regime caused ideological strain for Pērkonkrusts members. ${ }^{123}$ One concrete example is that of Jānis Simmanis, who worked for the Lettische Kartei, but who on November 18, 1942 (i.e., on Latvia's Independence Day) volunteered for 6-8 weeks' frontline service with the Schutzmannschaften, in order to 'prove [his] readiness to serve in the combat against Bolshevism outside [his] homeland as well.' However, once this young man had seen the reality of Bandenbekämpfung in Belarus, he was eager to return to his important work back home as soon as possible. ${ }^{124} \mathrm{In}$ addition to psychological trauma, this sentiment should also be seen in light of the fact that German National Socialism's expansionistic, imperialistic goals of conquering Lebensraum in the East were not congruent with the Latviacentred mentality of Pērkonkrusts.

\section{Conclusions}

Herein, I have not only proposed a definition of national socialism that is not dependent on Hitler, I have also argued that Pèrkonkrusts from Latvia constituted an anti-German form of national socialism. The defining feature of national socialism as a sub-genus of fascism is that its palingenetic ultranationalism is based on völkisch racialism. As such race and nation are essentially linked, but in a metaphysical way as much as a biological one. For national socialism, the Jews as a race are hostile to the aspirations of the Aryan family of nations, seeking to enslave and degrade them through various of phenomena of modernity, including capitalist materialism, hedonist consumerism, and Bolshevism. In order for society to move forward, national socialism requires a reconnection to the soil and the core values of the ancestors. The völkisch ideology idealizes the qualities of the northern European peoples, but in its various expressions can be more or less Nordicist or pan-Germanic, as the pro-Baltic and pro-Nordic, but anti-German nature of Pērkonkrusts ideological worldview demonstrates. This fact also offers a way of explaining the

\footnotetext{
122 Felder, Lettland, 239-240.

123 Felder calls it an 'ideological crisis': Ibid., 240.

124 Sīmanis to Artur Wilke, 13 January 1943, Rossiiskii Gosudarstvennyi Voennyi Arkhiv (RGVA; former Osobyi arkhiv), f. 5ook, op. 1, d. 769, l. 85 (roll 2).
} 
heretofore paradoxical issue of why Perrkonkrusts could collaborate with the German Nazi occupiers in unleashing genocide against the Jews of Latvia, while at the same time engaging in activities that ranged from subversive to resistance in pursuit of their own anti-German political agenda. It is thus my hope that we can move on to a comparative study of various national socialisms that allows the research to move beyond the dead-end assumptions of mimetic Hitlerism. ${ }^{125}$

125 For example, Henrik Ekberg has suggested that the ideological roots of Finnish national socialism lie not in German Hitlerism, but in the idea of the 'organic state' formulated the Swedish father of geopolitics, Rudolf Kjellén: Henrik Ekberg, Führerns trogna följeslagare: Den finländska nazismen 1932-1944 (Espoo: Schildt, 1991), 53, 72. 